\title{
Effect of sowing date on yield and yield components of bread wheat cultivars under environmental conditions of Sohag region
}

\author{
Othman M. El-Maghraby ${ }^{1}$, Khalaf Ali Fayez ${ }^{1}$, Fatma Abdel-Monsef $\mathrm{Abdo}^{2}$ and Hosna Mohamed \\ Sabra $^{2}$ \\ ${ }^{1}$ Botany Department, Faculty of Science, Sohag University. \\ ${ }^{2}$ Crop Physiology Dept., Field crop Res. Inst., Agric., Res. Center, Giza, Egypt.
}

Rec. 31 May, 2016 Accept. 4 July, 2016

\begin{abstract}
Afield experiment was conducted to determine the effect of three planting dates; early ( $25^{\text {th }}$ Oct.), optimum $\left(25^{\text {th }}\right.$ Nov.) and late $\left(25^{\text {th }}\right.$ Dec.) on yield, yield components and grain quality of four bread wheat (Triticum aestivum L.) cultivars; Shandaweel 1, Sids 12, Giza 168 and Sakha 93, at Shandaweel Agricultural Research Station, (ARC), during the two successive growing seasons of 2012/2013 and 2013/2014. Sowing dates and cultivars both significantly affected the number of spikes $/ \mathrm{m}^{2}$, number of kernels/spike, 1000-kernel weight, grain yield, straw yield, grain protein and carbohydrate percentage. Yield and yield components of wheat sown on November 25 were significantly increased compared to those sown on October 25 and December 25 from studied aspects. Delayed sowing adversely affected the yield and yield components and carbohydrate \%, while it increased the grain protein $\%$. Considering overall sowing performance of all cultivars, Shandaweel 1 produced highest yield followed by Sids 12, Giza 168 and Sakha 93.
\end{abstract}

Key words: Wheat, Sowing date, yield, yield components, grain protein, grain carbohydrate.

\section{Introduction}

Wheat (Triticumaestivum L.) is the most important cereal crop as the main stable food for the most world people. Improving the productivity of this crop is a main task due to its short supply which mandated improving about $50 \%$ of the needed wheat. The annual consumption of wheat grains in Egypt is about 14 million tons, while the annual local production is about 8.5 million tons in 2011 (Wheat Research Department). Therefore, great efforts must be continue to increase the productivity of cultivars to face the gap between the production and consumption in Egypt. Planting date is one of the most important agronomic factors involved in the wheat productivity per unit area. The use of different dates of planting allowed us to exposed wheat cultivars to different atmospheric temperature, which consider the major environmental factor drastically reducing wheat production. Therefore, optimum planting time is one of the important factors that influence the wheat yield appreciably. There are several studies that documented the effects of planting date on wheat. De et al. (1983) found that wheat yield production increased considerably by adjusting the sowing date to the best atmospheric temperature.Ansari et al.(1989) reported that delay sowing suppressed the yield caused by reduction in the yield contributing traits like number of tillers, number of grains per spike and grain yield. On the other hand, Raj et al. (1992) revealed that grain yield production of a wheat decreased when sowing date delayed after $28^{\text {th }}$ November. Rajput and Verma (1994) observed that optimum sowing gave higher grain yield than early and late sowing. Each day delay in sowing from $20^{\text {th }}$ November decreases grain yield by $39 \mathrm{~kg} \mathrm{ha}^{-1}$ per day (Singh and Uttam, 1999;Akhtar et al.,2006). They concluded that regardless of varieties/cultivars, better yields

* Corresponding author:

Dr. Hosna Mohamed Sabra 
were obtained when wheat was sown after 15th and before 30th November under Bahawalpur conditions. Tawfelis (2006) found that delaying sowing date reduced days to heading, days to maturity, number of kernels/spike, 1000-kernel weight (g) and grain yield $\mathrm{t} / \mathrm{ha}$ by an average of $13.65,13.47$, $25.77,27.31$ and $28.96 \%$, respectively, compared with the recommended sowing date. Ali et al.(2010) found that each successive delay in sowing beyond November 20 progressively decreased the grain yield significantly. Wheat grain yield can be increased by 10 to $80 \%$ with management of the sowing date, cultivar and environmental conditions (Coventry et al., 2011). Yield was reduced by 27.24 percent in sowing of December 30 as compared to November 10.After studying sowing date's effect on production potential of three wheat cultivars (Kumar et al., 2000). They reported better grain yield in $20^{\text {th }}$ November sowing than $1^{\text {st }}$ November or $10^{\text {th }}$ December sowings.High temperature during anthesis and crop maturity, initiated a significant decrease in the carbohydrate accumulation in developing grains of wheat as compared to crop plants sown under normal conditions (Hurkman et al., 2003; Ouda et al., 2005).They indicated that sowing wheat in October reduced grain yield by about $10 \%$, and delay of sowing date till the end of December reduced grain yield by about $16 \%$. Abdullah et al. (2007) sown two varieties of wheat at six sowing dates viz; 25 Oct., 10 Nov., 25 Nov., 10 Dec., 25 Dec. and 10 Jan. they found that sowing date effects for protein content were highly significant. Protein content increased with delayed sowing. The greatest increase in grain protein content in wheat occurs when heat stress is imposed early in grain filling (Castro et al., 2007; Qasim et al., 2008).They concluded that crop planted on November 15, produced higher grain yield as compared to late and early planting.Another study has showed that the highest values of number of tillers, spikes $\mathrm{m}^{-2}, 1000$-grain weight and grain yield per unit area were obtained when wheat was sown on mid of November but early or delayed planting caused a significant decrease in forenamed traits (El-Gizawy,2009; Feltaous, 2009).They studied the performance of twelve bread wheat genotypes under three sowing dates (25 November, 10 December and 25 December). The results indicated that delaying sowing date reduced number of spikes $/ \mathrm{m}^{2}, 1000$ kernel weight, number of kernels/spike, straw yield ( $\mathrm{t} / \mathrm{ha}$ ) and grain yield ( $\mathrm{t} / \mathrm{ha}$ ) compared with the optimum planting date.Seleiman et al. (2011) revealed that sowing date on $15^{\text {th }}$ November surpassed $1^{\text {st }}$ November, $1^{\text {st }}$ December and $15^{\text {th }}$ December sowing dates in all of yield studied parameters. Delaying sowing date of wheat for 30 or 60 days produced poor grains quality (decrease in carbohydrate, amino acids and protein contents) as compared with optimum sowing date and the reduction percentage reached to $2.31 \%$ and $6.23 \%$ in total carbohydrate (Hozayn et al., 2012). Mukund and Satendra (2014) found that significant differences in total soluble carbohydrate and starch content for all wheat genotypes with respect to all dates of sowing. The highest grain protein of wheat was observed for late sowing date (Ahmed and Fayyaz-ul-Hassan, 2015).

\section{Materials and methods:}

A field experiment to evaluate the effect of different sowing dates on yield, yield components and seed quality traits of wheat (Triticumaestivume L.) varieties was carried out at Shandaweel agricultural research station, ARC, Egypt during the two successive growing seasons of 2012/2013 and 2013/2014. The experiment comprised four wheat cultivars (Shandaweel1, Sids 12, Giza 168 and Sakha 93) and three sowing dates were October 25 (early), November 25(optimum) and December 25 (late) was laid out in randomized complete block design with stripe plot arrangement having three replications and a net plot size of $8.4 \mathrm{~m}^{2}$ (3.5 m length $\times 2.4 \mathrm{~m}$ width). Sowing was done by a seed drill to a depth of 2 to $3 \mathrm{~cm}$ at seed rate of $120 \mathrm{~kg} \mathrm{ha}$ ${ }^{1}, 12$ rows /plot with $20 \mathrm{~cm}$ inter-row spacing, and $5 \mathrm{~cm}$ from plant to plant was maintained. The recommended agricultural practices were applied from sowing to harvest. The observation recorded included spikes number $/ \mathrm{m}^{2}$, kernels number /spike, 1000-kernel weight $(\mathrm{gm})$, straw yield (ton/ha $\left.{ }^{-1}\right)$, grain yield 
(ton/ha ${ }^{-1}$ ), grain protein percentage and grain carbohydrate percentage. The results were analyzed statistically according to Snedecor and Cochran (1980). by MSTATC computer program in Stripe plot design. Duncan's test was used for comparing means (Duncan, 1955).

\begin{tabular}{|c|c|c|c|c|c|c|c|}
\hline Month & $\begin{array}{c}\text { Temp. } \\
\text { Mean max. } \\
\left({ }^{\circ} \mathbf{c}\right)\end{array}$ & $\begin{array}{c}\text { Temp. } \\
\text { Mean } \\
\text { min. }\left({ }^{\circ} \mathbf{c}\right)\end{array}$ & $\begin{array}{c}\text { Temp. } \\
\text { average } \\
\left({ }^{\circ} \mathbf{c}\right)\end{array}$ & $\begin{array}{c}\text { Relative } \\
\text { Humidity } \\
(\%)\end{array}$ & $\begin{array}{c}\text { Wind } \\
\operatorname{speed}(\mathrm{m} / \mathrm{sec})\end{array}$ & $\begin{array}{l}\text { Rain fall } \\
\text { (mm) }\end{array}$ & $\begin{array}{c}\text { Sunshine } \\
\%\end{array}$ \\
\hline \multicolumn{8}{|c|}{$(2012 / 2013)$} \\
\hline Nov. & 28.0 & 13.2 & 20.0 & 57 & 2.8 & 0.0 & 87 \\
\hline Dec. & 21.5 & 7.8 & 14.1 & 67 & 2.8 & 0.2 & 87 \\
\hline Jan. & 21.2 & 6.8 & 13.6 & 56 & 2.5 & 0.5 & 85 \\
\hline Feb. & 24.2 & 7.8 & 15.8 & 50 & 2.6 & 0.0 & 88 \\
\hline Mar. & 29.6 & 12.2 & 20.7 & 38 & 3.2 & 0.0 & 83 \\
\hline Apr. & 29.9 & 14.1 & 22.1 & 36 & 3.0 & 0.0 & 81 \\
\hline May. & 35.1 & 17.8 & 26.7 & 34 & 3.1 & 0.0 & 85 \\
\hline Av. & 27.1 & 11.4 & 19.0 & 48.3 & 2.9 & 0.7 & 85 \\
\hline \multicolumn{8}{|c|}{$(2013 / 2014)$} \\
\hline Nov. & 28.4 & 13.2 & 21.0 & 59 & 1.5 & 0.0 & 87 \\
\hline Dec. & 21.6 & 7.6 & 14.1 & 58 & 2.5 & 0.0 & 87 \\
\hline Jan. & 22.5 & 6.3 & 13.8 & 58 & 1.8 & 0.0 & 85 \\
\hline Feb. & 23.8 & 7.6 & 15.5 & 52 & 2.5 & 0.0 & 88 \\
\hline Mar. & 27.4 & 12.3 & 19.8 & 45 & 2.4 & 9.2 & 83 \\
\hline Apr. & 32.8 & 15.8 & 24.7 & 37 & 2.2 & 0.0 & 81 \\
\hline May. & 34.7 & 19.8 & 27.4 & 36 & 2.0 & 0.4 & 85 \\
\hline Av. & 27.3 & 11.8 & 19.5 & 49 & 2.1 & 9.6 & 85 \\
\hline
\end{tabular}

Table 1: Monthly meteorological data for 2012/2013 and 2013/2014 seasons

Results:

\section{Spikes number $/ \mathbf{m}^{2}$}

The results in Table 2 pointed out that spikes number $/ \mathrm{m}^{2}$ was significantly affected by wheat cultivars, planting date and their interaction in both seasons. Giza 168 achieved the maximum values $(385.3$ and 380.2) of spikes number $/ \mathrm{m}^{2}$ (Table 3 ), while Shakha 93 achieved the minimum values (356.5 and 348.4), in the first and second seasons, respectively. For the effect of planting date, it was observed that planting wheat in the optimum date gave the best result, in respect to spikes number $/ \mathrm{m}^{2}$ as compared to early or late dates, while late date gave the worst result in this concern. Early planting date caused significant reduction in spikes number $/ \mathrm{m}^{2}$ by 8.18 and $11.58 \%$, while the late date caused significant reduction by 44.06 and $31.12 \%$ compared with those of the optimum date in the first and second seasons, respectively. Concerning to the interaction effect, it was found that the best combination between the two factors in respect to spikes number $/ \mathrm{m}^{2}$ was obtained by planting Shandaweel 1 on the optimum date (486.0 and 441.0), whereas the worst combination was obtained by planting Sakha 93 on late date (243.0 and 278.8) in the first and second seasons, respectively. 


\begin{tabular}{|c|c|c|c|c|c|c|c|c|}
\hline S.O.V & D.F & $\begin{array}{c}\text { Spikes } \\
\text { number/ } \\
\mathbf{m}^{2} \\
\end{array}$ & $\begin{array}{c}\text { Kernels } \\
\text { number/ } \\
\text { spike } \\
\end{array}$ & $\begin{array}{c}\text { 1000- } \\
\text { kernel } \\
\text { weight }\end{array}$ & $\begin{array}{l}\text { Grain } \\
\text { yield }\end{array}$ & $\begin{array}{l}\text { Straw } \\
\text { yield }\end{array}$ & $\begin{array}{c}\text { Grain } \\
\text { protein } \\
\%\end{array}$ & $\begin{array}{c}\text { Grain } \\
\text { carbohydrate } \\
\%\end{array}$ \\
\hline & & \multicolumn{7}{|c|}{ Season 2012/2013 } \\
\hline Reps & 3 & 100.24 & 5.16 & 2.82 & 0.219 & 0.064 & 0.02 & 3.40 \\
\hline Dates (D) & 2 & $179760.7 * *$ & $200.14 * *$ & $177.51 * *$ & $40.232 * *$ & $53.754 * *$ & $6.79 * *$ & $124.87 * *$ \\
\hline Error (a) & 6 & 297.16 & 16.56 & 1.54 & 0.063 & 0.110 & 0.06 & 1.592 \\
\hline Varieties (V) & 3 & $2413.24 * *$ & $174.16^{* *}$ & $21.41 *$ & $2.89 * *$ & $6.070 * *$ & $3.52 * *$ & $26.68 *$ \\
\hline Error (b) & 9 & 109.28 & 12.07 & 4.25 & 0.096 & 0.429 & 0.19 & 0.985 \\
\hline D x V & 6 & $982.32 * *$ & $54.97 * *$ & $14.41 * *$ & 0.268 & 0.548 & 0.52 & $22.51 * *$ \\
\hline \multirow[t]{2}{*}{ Error (c) } & 18 & 153.30 & 9.80 & 1.57 & 0.112 & 0.235 & 0.24 & 1.712 \\
\hline & & \multicolumn{7}{|c|}{ Season $2012 / 2013$} \\
\hline Reps & 3 & 476.50 & 4.58 & 1.16 & 0.024 & 0.36 & 0.203 & 5.21 \\
\hline Dates (D) & 2 & $71214.75^{* *}$ & $549.25 * *$ & $501.54 * *$ & $30.22 * *$ & $74.33 * *$ & $4.14 * *$ & $155.04 * *$ \\
\hline Error (a) & 6 & 702.58 & 12.00 & 2.70 & 0.034 & 0.27 & 0.155 & 0.717 \\
\hline Varieties (V) & 3 & $2389.83 * *$ & $56.13 * *$ & $62.55 * *$ & $3.330 * *$ & $5.80 * *$ & $3.533 * *$ & $16.50 * *$ \\
\hline Error (b) & 9 & 172.37 & 3.82 & 6.19 & 0.160 & 0.32 & 0.209 & 2.29 \\
\hline D x V & 6 & $754.58 * *$ & 3.63 & 18.74 & $0.235^{*}$ & 0.48 & $1.112 * *$ & $26.52 * *$ \\
\hline Error (c) & 18 & 116.78 & 2.57 & 4.83 & 0.076 & 0.18 & 0.138 & 1.34 \\
\hline
\end{tabular}

Table 2: Mean squares of the analysis of variance for spikes number $/ \mathrm{m}^{2}$, Kernels number /spike , 1000-

kernel weight, grain yield, straw yield, grain protein $\%$ and grain carbohydrate $\%$ yield and its components characters over all sowing dates in the two growing seasons.

\section{Kernels number/spike:}

Data in Table 2 illustrate that the kernel number/spike was significantly affected by wheat cultivars and planting date in both seasons, and by their interaction only in the first season. The greatest values of kernels number/spike (61.33 and 51.83) were observed with cultivars of Sids 12 and Shandaweel 1, in the first and second seasons, respectively. The lowest values of kernels number/spike (52.75 and 46.67) were observed with cultivar of Sakha 93, in both seasons (Table 3). For effect of planting date, the results revealed that optimum date planting surpassed the other two planting dates, in both seasons.Early planting caused insignificant reduction Kernels number/spike $(5.17 \%)$ in the first season, and significant reduction in the second season (season (14.68\%). while the late planting caused significant reduction of (11.43 and $20.55 \%$ ) in the first and the second season, respectively. Concerning to the interaction effect, it was cleared that the highest values of kernels number/spike (65.75 and 58.75) were obtained by planting Shandaweel 1 variety on the optimum date, while the lowest values
(47.50 and 42.25) were obtained by planting Sakha 93 on late date, in the first and second seasons, respectively.

\section{0-Kernel weight (gm):}

The analysis of variance in Table 2 revealed that 1000 kernel weight was significantly affected by wheat cultivars and sowing date in both seasons, and by their interaction in the first season only. Data in Table 3 showed that Sids 12 had the highest values of 1000 kernel weight (44.77 and 48.25 g), while Giza 168 had the lowest values (41.76 and $43.43 \mathrm{~g}$ ), in the first and second seasons, respectively. The results in Table 3 showed that the early planting had the highest value of 1000 kernel weight $(45.51 \mathrm{~g})$ followed by optimum and late dates (44.24 and $39.21 \mathrm{~g}$ ), respectively, in the first season. While optimum date had the highest value $(50.76 \mathrm{~g})$ followed by early and late dates (44.91 and $39.57 \mathrm{~g}$ ), respectively, in the second season. The early sowing gave insignificant increment in 1000 kernel weight by $2.87 \%$ as compared to optimum sowing in the first season, while it gave a significant reduction by $11.52 \%$ in the second season. The 
late sowing date gave significant reduction ranged from 11.37 to $22.04 \%$ as compared to optimum sowing date in the first and second seasons, respectively. Concerning to the interaction effect, it was cleared that the highest values of 1000 kernel weight were obtained by planting Sakha 93 on the early date $(47.75 \mathrm{~g})$ in the first season and Sids 12 on the optimum

\begin{tabular}{|c|c|c|c|c|c|c|c|c|}
\hline \multirow{2}{*}{\multicolumn{2}{|c|}{ Trait }} & \multirow{3}{*}{$\begin{array}{l}\text { Cultivar } \\
\text { handaweel1 }\end{array}$} & \multicolumn{3}{|c|}{ Date } & \multirow{3}{*}{$\begin{array}{l}\text { Mean } \\
385.1 \mathrm{a}\end{array}$} & \multicolumn{2}{|c|}{ Reduction\% } \\
\hline & & & \multirow{2}{*}{$\begin{array}{c}\text { D125/10 } \\
416.3^{\mathrm{de}} \pm 5.54\end{array}$} & \multirow{2}{*}{$\begin{array}{c}\text { D2 } 25 / 11 \\
486.0^{\mathrm{a}} \pm 8.25\end{array}$} & \multirow{2}{*}{$\begin{array}{c}\text { D3 } 25 / 12 \\
253.0^{\mathrm{fg}} \pm 4.43\end{array}$} & & \multirow{2}{*}{$\begin{array}{c}\begin{array}{c}\text { D1- } \\
\text { D2/D2 }\end{array} \\
-14.34\end{array}$} & \multirow{2}{*}{$\begin{array}{c}\begin{array}{c}\text { D3- } \\
\text { D2/D2 }\end{array} \\
-47.94\end{array}$} \\
\hline \multirow{9}{*}{ 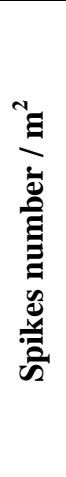 } & \multirow{4}{*}{ 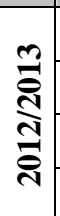 } & & & & & & & \\
\hline & & Sids 12 & $402.0^{\mathrm{e}} \pm 5.48$ & $449.5^{\mathrm{bc}} \pm 12.97$ & $250.0^{\mathrm{fg}} \pm 5.10$ & $367.2 b$ & -10.57 & -44.38 \\
\hline & & Giza 168 & $432.0^{\mathrm{cd}} \pm 4.24$ & $458.0^{\mathrm{b}} \pm 8.08$ & $266.0^{\mathrm{f}} \pm 4.40$ & $385.3 \mathrm{a}$ & -5.68 & -41.92 \\
\hline & & Sakha 93 & $411.0^{\mathrm{e}} \pm 3.42$ & $415.5^{\mathrm{de}} \pm 3.86$ & $243.0^{\mathrm{g}} \pm 3.70$ & $356.5 b$ & -1.08 & -41.52 \\
\hline & & Mean & $415.3^{b}$ & $452.30^{\mathrm{a}}$ & $253.00^{\mathrm{c}}$ & 373.53 & -8.18 & -44.06 \\
\hline & \multirow{4}{*}{ 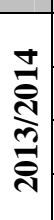 } & Shandaweel1 & $382.0^{\mathrm{de}} \pm 12.81$ & $441.0^{\mathrm{a}} \pm 4.20$ & $287.0^{\mathrm{h}} \pm 5.07$ & $370.0 \mathrm{ab}$ & -13.38 & -34.92 \\
\hline & & Sids 12 & $377.0^{\mathrm{e}} \pm 9.85$ & $410.5^{\mathrm{bc}} \pm 5.50$ & $281.8^{\mathrm{h}} \pm 4.63$ & $356.4 b$ & -8.16 & -31.35 \\
\hline & & Giza 168 & $395.0^{\text {cd }} \pm 13.00$ & $424.5^{b} \pm 2.63$ & $321.0^{\mathrm{g}} \pm 3.32$ & $380.2 \mathrm{a}$ & -6.95 & -24.38 \\
\hline & & Sakha 93 & $346.0^{\mathrm{f}} \pm 14.47$ & $420.5^{b} \pm 4.11$ & $278.8^{\mathrm{h}} \pm 2.39$ & $348.4 b$ & -17.72 & -33.70 \\
\hline & & Mean & $375.00^{b}$ & $424.10^{\mathrm{a}}$ & $292.10^{c}$ & 363.73 & -11.58 & -31.12 \\
\hline \multirow{9}{*}{ 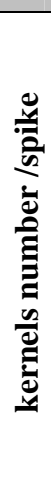 } & \multirow{4}{*}{ 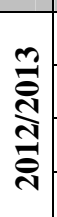 } & Shandaweel1 & $60.00^{b} \pm 1.41$ & $65.75^{\mathrm{a}} \pm 0.85$ & $52.75^{\mathrm{c}} \pm 1.60$ & $59.50 \mathrm{a}$ & -8.75 & -19.77 \\
\hline & & Sids 12 & $63.00^{\mathrm{ab}} \pm 1.29$ & $60.50^{b} \pm 1.04$ & $59.50^{b} \pm 1.55$ & $61.00 \mathrm{a}$ & 4.13 & -1.65 \\
\hline & & Giza 168 & $60.75^{b} \pm 3.75$ & $60.50^{b} \pm 1.66$ & $58.00^{b} \pm 1.78$ & $59.75 a$ & 0.41 & -4.13 \\
\hline & & Sakha 93 & $50.50^{\mathrm{cd}} \pm 0.65$ & $60.25^{b} \pm 0.85$ & $47.50^{\mathrm{d}} \pm 1.32$ & $52.75 b$ & -16.18 & -21.16 \\
\hline & & Mean & $58.56^{\mathrm{a}}$ & $61.75^{\mathrm{a}}$ & $54.43^{b}$ & 58.25 & -5.17 & -11.67 \\
\hline & \multirow{4}{*}{ 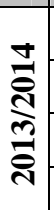 } & Shandaweel1 & $50.00^{c} \pm 0.82$ & $58.75^{\mathrm{a}} \pm 1.49$ & $46.75^{\mathrm{d}} \pm 0.85$ & $51.83 a$ & -14.89 & -20.43 \\
\hline & & Sids 12 & $47.25^{\mathrm{d}} \pm 1.31$ & $53.50^{b} \pm 1.44$ & $44.00^{\mathrm{ef}} \pm 0.58$ & $48.25 b$ & -11.68 & -17.76 \\
\hline & & Giza 168 & $46.75^{\mathrm{d}} \pm 0.85$ & $56.50^{\mathrm{a}} \pm 1.19$ & $43.00^{\mathrm{ef}} \pm 0.71$ & $48.75 \mathrm{ab}$ & -17.26 & -23.89 \\
\hline & & Sakha 93 & $45.00^{\mathrm{de}} \pm 1.22$ & $52.75^{\mathrm{b}} \pm 1.25$ & $42.25 f \pm 0.63$ & $46.67 b$ & -14.69 & -19.91 \\
\hline & & Mean & $47.25^{b}$ & $55.38^{\mathrm{a}}$ & $44.00^{b}$ & 48.88 & -14.68 & -20.55 \\
\hline \multirow{9}{*}{ 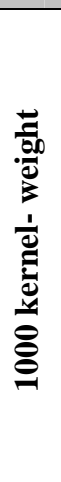 } & \multirow{4}{*}{ 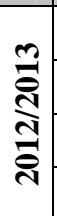 } & Shandaweel1 & $44.85^{\text {bcd }} \pm 0.89$ & $44.60^{\text {cde }} \pm 0.57$ & $40.22^{\mathrm{gh}} \pm 0.38$ & $43.22 \mathrm{a}$ & 0.56 & -9.82 \\
\hline & & Sids 12 & $46.80^{\mathrm{ab}} \pm 0.91$ & $46.13^{\mathrm{abc}} \pm 0.66$ & $41.38^{\mathrm{fg}} \pm 0.99$ & $44.77 \mathrm{a}$ & 1.45 & -10.30 \\
\hline & & Giza 168 & $42.65^{\text {ef }} \pm 0.94$ & $43.38^{\mathrm{def}} \pm 0.46$ & $39.25^{\mathrm{h}} \pm 0.48$ & $41.76 \mathrm{a}$ & -1.68 & -9.52 \\
\hline & & Sakha 93 & $47.75^{\mathrm{a}} \pm 1.16$ & $42.85^{\text {def }} \pm 0.61$ & $36.00^{i} \pm 0.70$ & $42.20 \mathrm{a}$ & 11.44 & -15.99 \\
\hline & & Mean & $45.51^{\mathrm{a}}$ & $44.24^{\mathrm{a}}$ & $39.21^{b}$ & 42.99 & 2.87 & -11.37 \\
\hline & \multirow{4}{*}{ 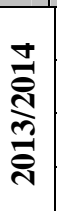 } & Shandaweel1 & $40.85^{\mathrm{cd}} \pm 0.74$ & $49.10^{b} \pm 0.93$ & $40.22^{\mathrm{cd}} \pm 0.48$ & $43.39 b$ & -16.80 & -18.09 \\
\hline & & Sids 12 & $47.95^{\mathrm{b}} \pm 1.08$ & $54.60^{\mathrm{a}} \pm 0.76$ & $42.20^{c} \pm 0.65$ & $48.25 \mathrm{a}$ & -12.18 & -22.71 \\
\hline & & Giza 168 & $42.70^{c} \pm 0.57$ & $50.25^{b} \pm 0.67$ & $37.35^{\mathrm{d}} \pm 1.10$ & $43.43 b$ & -15.02 & -25.67 \\
\hline & & Sakha 93 & $48.15^{b} \pm 2.71$ & $49.10^{b} \pm 0.50$ & $38.50^{\mathrm{d}} \pm 0.37$ & $45.25 \mathrm{ab}$ & -1.93 & -21.59 \\
\hline & & Mean & $44.91^{b}$ & $50.76^{\mathrm{a}}$ & $39.57^{\mathrm{c}}$ & 45.08 & -11.52 & -22.04 \\
\hline
\end{tabular}

Table 3: Spikes number $/ \mathrm{m}^{2}$, kernels number /spike and 1000 kernel-weight for the four bread wheat cultivars under three planting dates in the two growing seasons. 
date $(54.60 \mathrm{~g})$ in the second season, while the lowest values were obtained by planting Sakha 93 on the late date $(36.00 \mathrm{~g})$ in the first season and Giza 168 on the late date in the second season.

\section{Grain yield (t/ha):}

The analysis of variance in Table 2 showed that the grain yield significantly affected by wheat cultivars and planting date in both seasons, and by their interaction in the second season only. The data in Table 4 revealed that Shandaweel 1registered the maximum values of grain yield (6.63 and $6.24 \mathrm{t} / \mathrm{ha})$ in both seasons, while Sakha 93 registered the minimum values (5.47 and 5.02t/ha) in both seasons. For the effect of planting date, it was observed that planting wheat in the optimum date gave the best result (7.30 and $6.50 \mathrm{t} / \mathrm{ha})$, in respect to grain yield as compared to early and late dates in the first and second seasons, respectively, while late date gave the worst result (4.25 and $4.02 \mathrm{t} / \mathrm{ha})$ in both seasons. Early planting date caused significant reduction in grain yield by an average of 10.47 and $3.20 \%$ compared with the optimum planting date, while the late date caused significant reduction of 41.72 and $38.08 \%$ compared with the optimum date in the first and second seasons, respectively. For the interaction between the two factors, it was found that the best combination between the two factors in respect to grain yield (8.02 and $7.28 \mathrm{t} / \mathrm{ha}$ ) was obtained by planting Shandaweel 1 under the optimum date, whereas the worst combination was obtained by planting Sakha 93 under late date (3.98 and $3.70 \mathrm{t} / \mathrm{ha}$ ) in the first and second seasons, respectively.

\begin{tabular}{|c|c|c|c|c|c|c|c|c|}
\hline \multirow{2}{*}{\multicolumn{2}{|c|}{ Trait }} & \multirow{2}{*}{ Cultivar } & \multicolumn{3}{|c|}{ Date } & & \multicolumn{2}{|c|}{ Reduction\% } \\
\hline & & & D125/10 & D2 $25 / 11$ & D3 $25 / 12$ & Mean & D1-D2/D2 & D3-D2/D2 \\
\hline \multirow{9}{*}{ 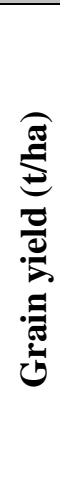 } & \multirow{5}{*}{$\frac{m}{\stackrel{3}{\bar{N}}}$} & Shandaweel & $7.370^{b} \pm 0.22$ & $8.020^{\mathrm{a}} \pm 0.10$ & $4.500^{\mathrm{g}} \pm 0.07$ & $6.630^{\mathrm{a}}$ & -8.10 & -43.89 \\
\hline & & Sids 12 & $6.695^{\mathrm{cd}} \pm 0.38$ & $7.545^{\mathrm{ab}} \pm 0.08$ & $4.330^{\mathrm{g}} \pm 0.06$ & $6.190^{\mathrm{ab}}$ & -11.27 & -42.61 \\
\hline & & Giza 168 & $6.160^{\mathrm{ef}} \pm 0.26$ & $7.142^{\mathrm{bc}} \pm 0.08$ & $4.220^{\mathrm{g}} \pm 0.07$ & $5.841^{b c}$ & -13.75 & -40.91 \\
\hline & & Sakha 93 & $5.938^{\mathrm{f}} \pm 0.04$ & $6.517^{\mathrm{de}} \pm 0.16$ & $3.983^{g} \pm 0.04$ & $5.479^{c}$ & -8.88 & -38.88 \\
\hline & & Mean & $6.54^{\mathrm{b}}$ & $7.30^{\mathrm{a}}$ & $4.25^{\mathrm{c}}$ & 6.04 & -10.47 & -41.72 \\
\hline & & Shandaweel & $7.075^{\mathrm{a}} \pm 0.13$ & $7.285^{\mathrm{a}} \pm 0.11$ & $4.372^{\mathrm{f}} \pm 0.14$ & $6.244^{\mathrm{a}}$ & -2.88 & -39.99 \\
\hline & $\overline{8}$ & Sids 12 & $6.497^{b c} \pm 0.23$ & $6.858^{\mathrm{ab}} \pm 0.08$ & $4.045^{\mathrm{fg}} \pm 0.03$ & $5.800^{\mathrm{ab}}$ & -5.26 & -41.02 \\
\hline & 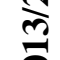 & Giza 168 & $6.023^{\mathrm{de}} \pm 0.19$ & $6.110^{\text {cd }} \pm 0.12$ & $3.995^{\mathrm{fg}} \pm 0.02$ & $5.376^{b c}$ & -1.42 & -34.62 \\
\hline & & Sakha 93 & $5.602^{\mathrm{e}} \pm 0.29$ & $5.775^{\mathrm{de}} \pm 0.10$ & $3.705^{\mathrm{g}} \pm 0.09$ & $5.028^{\mathrm{c}}$ & -3.00 & -35.84 \\
\hline & & Mean & $6.29^{\mathrm{a}}$ & $6.50^{\mathrm{a}}$ & $4.02^{b}$ & 5.61 & -3.20 & -38.08 \\
\hline \multirow{10}{*}{ 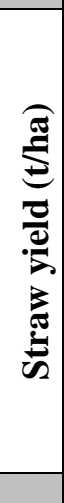 } & \multirow{5}{*}{ 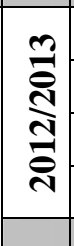 } & Shandaweel & $10.39^{b c} \pm 0.23$ & $10.18^{\mathrm{c}} \pm 0.12$ & $7.925^{\mathrm{de}} \pm 0.28$ & $9.499^{b}$ & 2.06 & -22.15 \\
\hline & & Sids 12 & $11.91^{\mathrm{a}} \pm 0.41$ & $11.75^{\mathrm{a}} \pm 0.19$ & $8.057^{\mathrm{d}} \pm 0.25$ & $10.57^{\mathrm{a}}$ & 1.36 & -31.43 \\
\hline & & Giza 168 & $10.98^{\mathrm{b}} \pm 0.22$ & $10.23^{b c} \pm 0.35$ & $7.217^{\mathrm{ef}} \pm 0.25$ & $9.478^{b}$ & 7.33 & -29.45 \\
\hline & & Sakha 93 & $10.13^{\mathrm{c}} \pm 0.14$ & $9.658^{\mathrm{c}} \pm 0.24$ & $6.790^{f} \pm 0.15$ & $8.858^{b}$ & 4.89 & -29.70 \\
\hline & & Mean & $10.85^{\mathrm{a}}$ & $10.46^{\mathrm{a}}$ & $7.49^{b}$ & 9.60 & 3.73 & -28.33 \\
\hline & \multirow{4}{*}{ 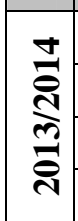 } & Shandaweel & $10.02^{\mathrm{e}} \pm 0.17$ & $10.61^{\text {cde }} \pm 0.32$ & $7.082^{g} \pm 0.10$ & $9.241^{b}$ & -5.56 & -33.25 \\
\hline & & Sids 12 & $11.40^{\mathrm{b}} \pm 0.27$ & $12.42^{\mathrm{a}} \pm 0.39$ & $8.030^{\mathrm{f}} \pm 0.28$ & $10.62^{\mathrm{a}}$ & -8.21 & -35.35 \\
\hline & & Giza 168 & $10.93^{\mathrm{bcd}} \pm 0.22$ & $11.04^{b c} \pm 0.10$ & $6.680^{g} \pm 0.25$ & $9.549^{b}$ & -1.00 & -39.49 \\
\hline & & Sakha 93 & $10.14^{\mathrm{e}} \pm 0.30$ & $10.27^{\mathrm{de}} \pm 0.28$ & $6.780^{g} \pm 0.10$ & $9.063^{b}$ & -1.27 & -33.98 \\
\hline & & Mean & $10.62^{\mathrm{a}}$ & $11.09^{\mathrm{a}}$ & $7.14^{b}$ & 9.62 & -4.24 & -35.59 \\
\hline
\end{tabular}

Table 4: Grain yield t/ha and straw yield t/ha of the four bread wheat cultivars under three planting dates in the two growing seasons. 


\section{Straw yield (t/ha):}

The analysis of variance in Table 2 showed that straw yield was significantly affected by wheat cultivars and planting dates, while it was insignificantly affected by the interaction between the two factors. The results in Table 4 revealed that Sids 12 had the highest values of straw yield (10.57 and $10.62 \mathrm{t} / \mathrm{ha})$ in both seasons, while Sakha 93 had the lowest values (8.85 and $9.06 \mathrm{t} / \mathrm{ha}$ ), in the first and second seasons, respectively. The early sowing date had the highest value of straw yield (10.85 t/ha) followed by optimum and late dates (10.46 and $7.49 \mathrm{t} / \mathrm{ha})$, respectively, in the first season, while the optimum date had the highest value (11.09 t/ha) followed by early and late dates (10.62 and $7.14 \mathrm{t} / \mathrm{ha})$, respectively, in the second season. It is clear that the early sowing date gave insignificant increment in straw yield by $3.73 \%$ as compared to optimum sowing in the first seasons and gave insignificant reduction percentage by $4.24 \%$ in the second season. While the late sowing gave significant reduction by an average of 28.33 to $35.59 \%$ as compared to optimum sowing in the first and second seasons, respectively. Concerning to the interaction effect, it is clear that the highest values of straw yield were obtained by planting Sids 12 on the early planting date (11.91 t/ha) in the first season and by planting Sids 12 on the optimum date $(12.42 \mathrm{t} / \mathrm{ha})$ in the second season. On the other hand, the lowest values were obtained by planting Sakha 93 on the late date $(6.79 \mathrm{t} / \mathrm{ha})$ in the first season and Giza 168 on the late date $(6.68$ $\mathrm{t} / \mathrm{ha}$ ) in the second season.

\section{Grain protein \%:}

The analysis of variance in Table 2 of grain protein \%exhibited significant differences among wheat varieties, sowing date and their interaction in second season. Grain protein content $(\%)$ mean values in Table 5 indicated that the greatest values were recorded in Giza $168(10.94$ and $10.77 \%)$ in the first and second seasons, respectively, while the lowest values were recorded in Sakh 93 (9.78\%) in the first season and Sids 12 (9.61\%) or Sakh 93 $(9.74 \%)$ in the second season. As to the effect of planting date, data stated that the highest values of grain protein content (\%)were obtained under late date planting (11.03 and $10.65 \%$ ) in the first and the second seasons, respectively, while the lowest values were obtained under early planting $(9.73$ and $9.63 \%$ ) in the first and second seasons, respectively. The early planting compared to optimum planting gave significant reduction by $5.72 \%$ in the first season and insignificant reduction by $4.52 \%$ in the second season, while the late planting gave significant increment by $6.88 \%$ in the first season and insignificant increment by $5.55 \%$ in the second season. For the interaction between the two factors, it was cleared that the highest values of grain protein content $(\%)$ were obtained by planting Shandaweel 1 on the late date $(11.71 \%)$ in the first season and Giza 168 on the optimum date $(11.13 \%)$ in the second season, while the lowest values were obtained by planting Sakha 93 on the early date $(8.96 \%)$ and Sids 12 under the optimum date $(9.0 \%)$ in the second season.

\section{Grain carbohydrate\%:}

The analysis of variance in Table 2 revealed that the grain carbohydrate $(\%)$ was significantly affected by the tested varieties, planting dates and their interaction in both seasons. Data in Table (5) showed that the highest values of carbohydrate content $(74.40$ and $71.65 \%$ ) were obtained by planting Giza 168 in both seasons, while the lowest values (71.14 and 68.96\%) were obtained by planting Sakka 93 in the first season or Shandaweel 1 in the second season, respectively. For the effect of planting date, the data revealed that the mean values of carbohydrate content were $74.14,73.82$ and $68.99 \%$ in the first season and $72.26,71.23$ and $66.43 \%$ in the second season under early, optimum and late planting, respectively. The early planting compared to the optimum planting resulted in insignificant increment of carbohydrate by average of 0.97 and $1.45 \%$, while the late planting resulted in significant reduction by average of 6.05 and $6.74 \%$ in the first and second seasons, respectively. In respect to the interaction effect, it was cleared that planting Giza 168 under early date, the carbohydrate content was75.92\% in the first season and for Sakha 
93 under optimum date was $74.04 \%$ in the second season., whereas planting Sakha 93 in the first season the carbohydrate content was
$66.19 \%$ and for handaweel 1 , in the second season was $63.41 \%$.

\begin{tabular}{|c|c|c|c|c|c|c|c|c|}
\hline \multirow{2}{*}{\multicolumn{2}{|c|}{ Trait }} & \multirow{2}{*}{ Cultivar } & \multicolumn{3}{|c|}{ Date } & & \multicolumn{2}{|c|}{ Reduction \% } \\
\hline & & & D125/10 & D2 $25 / 11$ & D3 $25 / 12$ & Mean & $\begin{array}{c}\text { D1- } \\
\text { D2/D2 }\end{array}$ & $\begin{array}{c}\text { D3- } \\
\text { D2/D2 }\end{array}$ \\
\hline \multirow{9}{*}{ 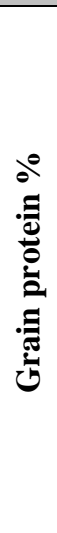 } & \multirow{4}{*}{ 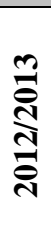 } & Shandaweel1 & $10.05^{\mathrm{cd}} \pm 0.16$ & $10.31^{\mathrm{cd}} \pm 0.24$ & $11.71 \mathrm{a} \pm 0.12$ & $10.69^{\mathrm{ab}}$ & -2.52 & 13.58 \\
\hline & & Sids 12 & $9.62^{\mathrm{de}} \pm 0.24$ & $10.07^{\mathrm{cd}} \pm 0.10$ & $10.40^{\mathrm{cd}} \pm 0.24$ & $10.03^{\mathrm{bc}}$ & -4.47 & 3.28 \\
\hline & & Giza 168 & $10.28^{\mathrm{cd}} \pm 0.15$ & $11.26^{\mathrm{ab}} \pm 0.19$ & $11.26^{\mathrm{ab}} \pm 0.35$ & $10.94^{\mathrm{a}}$ & -8.70 & 0.09 \\
\hline & & Sakha 93 & $8.96^{\mathrm{e}} \pm 0.27$ & $9.62^{\mathrm{de}} \pm 0.22$ & $10.76^{\mathrm{bc}} \pm 0.13$ & $9.78^{c}$ & -6.86 & 11.85 \\
\hline & & Mean & $9.73^{c}$ & $10.32^{b}$ & $11.03^{\mathrm{a}}$ & 10.36 & -5.72 & 6.88 \\
\hline & \multirow{4}{*}{ 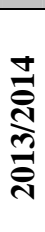 } & Shandaweel1 & $9.45^{\mathrm{de}} \pm 0.22$ & $10.66^{\mathrm{a}} \pm 0.19$ & $11.00^{\mathrm{a}} \pm 0.25$ & $10.37^{\mathrm{ab}}$ & -11.35 & 3.19 \\
\hline & & Sids 12 & $9.91^{\mathrm{cd}} \pm 0.07$ & $9.00^{\mathrm{e}} \pm 0.21$ & $9.91^{\mathrm{cd}} \pm 0.14$ & $9.613^{b}$ & 10.11 & 10.11 \\
\hline & & Giza 168 & $10.07^{\mathrm{bc}} \pm 0.18$ & $11.13^{\mathrm{a}} \pm 0.22$ & $11.11^{\mathrm{a}} \pm 0.32$ & $10.77^{\mathrm{a}}$ & -9.52 & -0.18 \\
\hline & & Sakha 93 & $9.09^{\mathrm{e}} \pm 0.16$ & $9.57^{\text {cde }} \pm 0.19$ & $10.57^{\mathrm{ab}} \pm 0.16$ & $9.747^{b}$ & -5.02 & 10.45 \\
\hline & & Mean & $9.63^{b}$ & $10.09^{\mathrm{ab}}$ & $10.65^{\mathrm{a}}$ & 10.12 & -4.52 & 5.55 \\
\hline \multirow{9}{*}{ 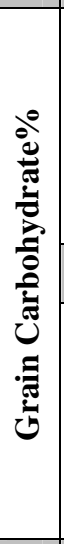 } & \multirow{4}{*}{ 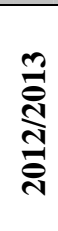 } & Shandaweel1 & $74.43^{\mathrm{abc}} \pm 0.76$ & $73.13^{\text {bcd }} \pm 1.22$ & $67.34^{\mathrm{f}} \pm 1.16$ & $71.63^{b}$ & 1.78 & -7.92 \\
\hline & & Sids 12 & $74.82^{\mathrm{ab}} \pm 0.75$ & $70.16^{\mathrm{e}} \pm 1.03$ & $69.77^{\mathrm{e}} \pm 1.55$ & $71.58^{b}$ & 6.64 & -0.56 \\
\hline & & Giza 168 & $75.92^{\mathrm{a}} \pm 0.88$ & $74.62^{\mathrm{abc}} \pm 0.73$ & $72.67^{\mathrm{cd}} \pm 1.26$ & $74.40^{\mathrm{a}}$ & 1.74 & -2.61 \\
\hline & & Sakha 93 & $71.41^{\mathrm{de}} \pm 0.76$ & $75.82^{\mathrm{a}} \pm 1.21$ & $66.19^{f} \pm 1.32$ & $71.14^{\mathrm{b}}$ & -5.82 & -12.70 \\
\hline & & Mean & $74.14^{\mathrm{a}}$ & $73.43^{\mathrm{a}}$ & $68.99^{b}$ & 72.19 & 0.97 & -6.05 \\
\hline & \multirow{4}{*}{ 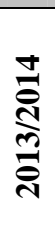 } & Shandaweel1 & $73.22^{\mathrm{ab}} \pm 0.51$ & $70.26^{\mathrm{cd}} \pm 0.73$ & $63.41^{\mathrm{f}} \pm 0.94$ & $68.96^{b}$ & 4.21 & -9.75 \\
\hline & & Sids 12 & $72.08^{\mathrm{bc}} \pm 0.57$ & $69.55^{\mathrm{de}} \pm 0.63$ & $67.87^{\mathrm{e}} \pm 0.63$ & $69.83^{\mathrm{ab}}$ & 3.64 & -2.42 \\
\hline & & Giza 168 & $73.28^{\mathrm{ab}} \pm 0.50$ & $71.08^{\text {cd }} \pm 0.58$ & $70.59^{\text {cd }} \pm 0.72$ & $71.65^{\mathrm{a}}$ & 3.10 & -0.69 \\
\hline & & Sakha 93 & $70.46^{\mathrm{cd}} \pm 0.85$ & $74.04^{\mathrm{a}} \pm 0.42$ & $63.84^{\mathrm{f}} \pm 0.76$ & $69.45^{\mathrm{ab}}$ & -4.84 & -13.78 \\
\hline & & Mean & $72.26^{\mathrm{a}}$ & $71.23^{\mathrm{a}}$ & $66.43^{b}$ & 69.97 & 1.45 & -6.74 \\
\hline
\end{tabular}

Table 5: Grain protein \% and grain ccarbohydrate\% of the four bread wheat cultivars under three planting dates in the two growing seasons.

\section{Discussion:}

The highest number of spikes $/ \mathrm{m}^{2}$ for all cultivars of wheat was obtained with optimum sowing $\left(25^{\text {th }}\right.$ Nov.) followed by early sowing ( $25^{\text {th }}$ Oct.). This may be due to the effect of environmental condition. In early sown wheat faced high temperature stress from germination to the vegetative stage, resulting in a reducing tillering capacity and poor crop establishment. On the other hand, in late sown wheat faced low temperature stress at germination and through the seedling stage, resulting in a poor germination and fewer tillers. These results are in accordance with (Ansari et al.,1989).

Both early and late dates showed a noticeable significant decrease in Kernels number/spike it might be due favorable 
temperature at optimum sown. Less number of kernels /spike in early sowing may be due to high temperature from emergence to double ridge stage (GS1) of crop, which effect on floret formation then reduced number of kernels/spike. With low temperature during anthesis stage (when wheat sown early) may be caused an erratic occurrence of aborted spikelets at the base, centre or tip of the spikes. It is also cause as sterile florets in parts of the entire spike. These results are in accordance with those of (Seleiman et al., 2011). On the other hand, the lower kernels number/spike in all cultivars was observed at late sown; it might be due to less production of photosynthates due to shorter growing period. High temperature during the reproductive phase can cause pollen sterility consequently, decreased number of fertile spikes or fewer grain per spike. These results are in line with those of (Ansari et al.,1989 andFeltaous, 2009).

Results of 1000 kernels weight indicated that early and optimum sowing produced higher 1000 kernels weight as compared with late sowing. These findings are strongly supported by those of(El-Gizawy, 2009), who reported that decreased 1000-kernel weight with early and late sowing as compared to normal sowing. All cultivars showed decrease in 1000 grain weight as a result of late sowing. It might be due to favorable temperature at growth stages of crop, especially at grain filling period at early and normal sowing and high temperature during grain filling under late sowing.

Results of grain yield showed that all wheat cultivars sown on 25 November was the highest grain yield followed by 25 Oct. then $25 \mathrm{Dec}$. These results are in line with those of (Rajput and Verma, 1994; Kumar et al.,2000 andOuda et al., 2005), whoobserved that normal sowing gave higher grain yield than late and early sowing. Lower grain yield in early and late sowing was mainly due to lower germination, less number of spikes $/ \mathrm{m}^{2}$, less number of kernels/spike and lower 1000kernels weight. These results are in accordance with those of (Ansari et al.,1989), who reported that delay sowing suppressed the yield, caused by reduction in the yield contributing traits like number of tillers, number of grains per spike and grain yield.Differences in grain yield among cultivars might be attributed to their genetic diversity. Although, the higher reduction in grain yield of Shandaweel 1 from optimum to late sowing compared to others cultivars but, it was the best cultivars under heat stress condition. It might be due to higher production of Shandaweel 1 than other cultivars under optimum sowing.

Higher straw yield in early and optimum sowing was due to increased vegetative growth, plant height and higher number of spikes $/ \mathrm{m}^{2}$ than the late sowing. On the other hand, lower straw yield in late planting was due to the fact that plant got unfavorable environment such high temperature at vegetative stage. As a result, the plant became thinned and produced fewer tillers which in turn decreased the straw yield. Higher straw yield in Sids 12 can be attributed to more 1000- kernel weight, infertile tellers and increased vegetative growth. These results are in line with those obtained by (Feltaous, 2009).

Grain protein percentage is the most important parameter which is significantly affected by change in sowing date. Our present study indicated that grain protein (\%) increased with delayed sowing. These results are in line with results of Ahmed and Fayyazul-Hassan (2015), who found that the highest grain protein was observed for late sowing date. Also high temperature in the post anthesis period of late sown wheat shortened the grain filling period resulting in a smaller endosperm, lower grain weight and increased protein content.

The grain carbohydrate percentage decreased with delayed sowing. These results are agreement with (Mukund and Satendra, 2014), who found that significant differences in total soluble carbohydrate and starch content for all the genotypes with respect to all dates of sowing. The reduction in the carbohydrate percentage in the produced wheat grains after the exposure to high temperature stress may be attributed to a reduction in endosperm cell size. 


\section{References:}

Abdullah, M., ur-Rehman, A., Ahmad, N. and Raeul, J. (2007). Planting time effect on grain and quality characteristics of wheat. Pak. J. Agri. Sci., 44(2): 200-202

Ahmed, M. and ul-Hassan, F. (2015). Response of spring wheat (triticum aestivum 1.) Quality traits and yield to sowing date. Plos one 10(4): e0126097. Doi:10.1371.

Akhtar, M., Cheema, M.S., Jamil, M. and Ali, L. (2006). Effect of time of sowing on some important characters of wheat, Triticum aestivum genotypes. J. Agric. Res., 44(4):255-259.

Ali, M.A., Ali, M. Sattar, M. and Ali, L. (2010). Sowing date effect on yield of different wheat varieties. J. Agric. Res., 48(2): 157-162.

Ansari, A.H., Khushak, A.M., Sethar, M.A., Ariam, N.A. and Emon, M.Y.M. (1989). Effect of sowing dates on growth and yield of wheat cultivars. Pak. J. Sci. Ind. Res., 32: 39-42.

Castro, M., Peterson, C.J., Rizza, M.D., Dellavalle, P.D. Vazquez, D. Ibanez, V. and Ross, A. (2007). Influence of heat stress on wheat grain characteristics and protein molecular weight distribution. In: Wheat Production in Stressed Environment. (Eds HT Buk, JE Nisi, N Salomon) pp. 365-371. (Springer: Dordrecht, The Netheriands).

Coventry, R.K, Gupta, D.R., Poswal, R.S., Chhokar, R.S., Sharma, R.K., Yadav, V.K., Gill, S.C. Mehta, A., Kleemann, S.G.L., Bonamano, A., Cummins, J.A. (2011). Wheat quality and productivity as affected by varieties and sowing time in Haryana, India. Field Crops Res., 123(3): 214-225.
De, R., Satan, G., Turkhede, B.B., La, 1.R.B., Singh, R.K. and Giri, G. (1983). Response of wheat cultivars to date of sowing under dry land conditions. J. Agri. Sci., U.K. 10: 727-733.

Duncan, D.B. (1955). Multiple Range and Multiple F. Tests. Biometrics 11:1. Eno, C.F. (1966). Chicken Manure. Fla. Agr. Exp. Sta. Circ. S-140.

El-Gizawy, N. (2009). Effect of Planting Date and Fertilizer Application on Yield of Wheat under No till System. World J. Agri. Sci., 5: 777-783.

Feltaous, Y.M. (2009). Performance and stability of some bread wheat genotypes under different planting dates in Upper Egypt. M.Sc. Thesis, Fac. of Agric., Assiut Univ., Egypt.

Hozayn, M., Abd El-Monem, A.A., Ebtihal, M., Abd El-Hameed and Tawfik, M.M. (2012). Mitigating Global Warming Impact on Wheat Productivity in Egypt. Aus. J. of Basi. and Appl. Sci., 6(10): 525531.

Hurkman, W.J., McCue, K.F. and Altenbach, S.B. (2003). Effect of temperature on expression of genes encoding enzymes for starch biosynthesis in developing wheat endosperm. Plant. Sci., 164: 873881.

Kumar, S., Bangarwa, A.S. and Kadian, V.S. (2000). Response of wheat varieties to sowing dates and nitrogen levels. Ann. Agric. Bio. Res., 5: 99-103.

Mukund, K. and Satendra, K. (2014). Evaluation of different wheat (Triticum aestivum L.) varieties for terminal heat stress on the basis of their morpho-physiological and 
yield traits. Progressive agric., 14 (2): 251-263.

Ouda, S.A., El-Marsafawy, S.M., ElKholy, M.A. and Gaballah, M.S. (2005). Simulating the effect of Water Stress and Different Sowing Dates on Wheat Production in South Delta. J. App. Sci. Res., 1: 268-276.

Qasim, M., Qamer, M., Faridullah and Alam, M. (2008). Sowing dates effect on yield and yield components of different wheat varieties. J. Agric. Res. 46(2):135140.

Raj, S., Singh, D. and Rao, U.V. (1992). Effect of date of sowing and row spacing on the yield of wheat. Crop Res. (Hisar). 5: 199-206.

Rajput, R.L. and Verma. (1994). Effect of sowing dates on the yield of different varieties of wheat in Chambal Command Area of Madhya Pradesh Bharyiya Krishi
Anusandhan Patrika. Ind. J. Agron., 9: 165-169.

Seleiman, M., Ibrahim, M., Abdel-Aal, S. and Zahran, G. (2011). Effect of Sowing Dates on Productivity, Technological and Rheological Characteristics of Bread Wheat. J. Agro. Crop Sci., 2(1): 1-6.

Singh, V.P.N. and Uttam, S.K. (1999). Influence of sowing dates on yield of wheat cultivars under saline sodic conditions in Central Utter Pradesh. Ind. Agric., 38(1): 64-68.

Snedecor, G.W. and Cochran,W.G. (1980). Statistical methods.7th ed. Lowa State Unv. Press.Ames. Lowa, U.S.A.

Tawfelis, M.B. (2006). Stability parameters of some bread wheat genotypes (Triticum aestivum L.) in new and old lands under Upper Egypt conditions, Egypt J. plant Breed. 10(1): 223-246. 


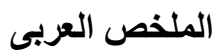

تأثثير ميعاد الزراعة على المحصول ومكوناته لأصناف قمح الخبز تحت الظروف البيئية ل منطقة سوهاج ** **

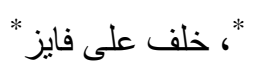
- كلية العلوم - جامعة سو هاج. ** قسم بحوث فسيولوجيا المحاصيل ـ معهد بحوث المحاصيل الحقلية - مركز البحوث الزر اعية بالجيزة

ديسمبر على محصول القمح

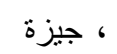

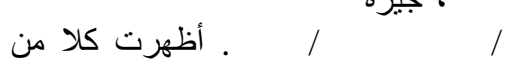

ملخص أجريت تجربة حقلية لتحديد نأثير ثلاث مواعيد زراعية وهى وهي

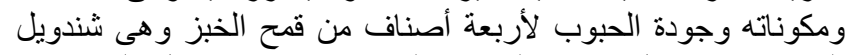

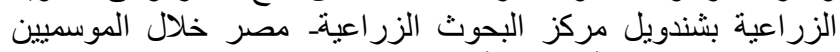

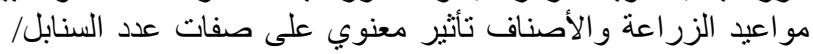
الحبوب، محصول القش، نسبة البروتين والكربو هيدرات فئرئ في الحبة. ديسمبر بالنسبة لصفات ألمحصول ولئية ومكوناته.

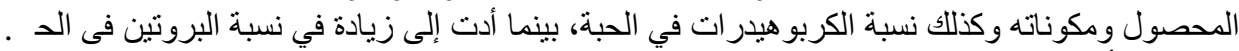

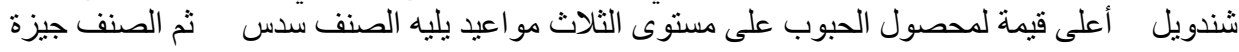

